\title{
THE CONSTITUTIONAL COMMON LAW OF TREATY INTERPRETATION: \\ A REPLY TO THE FORMALISTS
}

\section{Phillip R. TRImble $\dagger$}

If hard cases make bad law, then the ABM Treaty reinterpretation controversy demonstrates the opposite corollary: easy cases make good law. Moreover, far from representing a "constitutional crisis," as suggested by Senate opponents of the ABM Treaty reinterpretation and by Professor Koplow, the controversy actually demonstrates another opposite corollary: substantive law conflict between the President and the Senate represents a constitutionally appropriate process to produce constitutional law. The clash between the President and Congress. was not a constitutional crisis, but rather a good example of how constitutional common law is formed in the area of foreign affairs and separation of powers.

One may not have gathered this perception by following the debate and focusing on the views of the principal protagonists. Senator Biden opened the Senate hearings by proclaiming a "constitutional crisis" and by staking out a position denying presidential power to reinterpret a treaty under certain circumstances. On behalf of the Reagan Administration, Judge Sofaer responded with an opposing position, but he also conceded an absence of presidential power to reinterpret a treaty under certain, apparently narrower, circumstances. Professor Koplow proposes yet another set of circumstances under which presidential power to reinterpret a treaty would be denied, determined by balancing eight factors. He argues that "[i]f, on balance, one concludes that the original interpretation has - via the operation of these eight factors - become "entrenched" in domestic law, then the President may not unilaterally depart from it. . . . and it can be changed only by a subsequent lawmaking activity that is of equal stature under the Constitution." These three positions are different, but they have much more in common than one might gather in the midst of the rhetorical storm. All the protagonists accept the notion that, under some circumstances, a "correct" interpretation of a treaty can be frozen at the time the Senate gave its

$\dagger$ Professor of Law, University of California, Los Angeles.

1 Koplow, Constitutional Bait and Switch: Executive Interpretation of Arms Control Treaties, 137 U. PA. L. Rev. 1353, 1425-26 (1989). 
advice and consent to ratification. Thus they all share a fundamental - and fundamentally false - conception of law and legal development. It is called "entrenchment," and it portrays this part of treaty law as a set of static legal rules, unchanged in meaning from their inception, and unchangeable except through the same formal process that produced the rules in the first place. That view of law is not consistent with other examples of law and legal development. Law changes in response to new circumstances, and the "correct" interpretation of a treaty is no exception.

The more important question is how entrenched rules, even if they existed, could change. Indeed the question of "entrenchment" of law and the process of legal change cannot be separated. Yet in the debate about the constitutional principles governing the ABM Treaty interpretation, the protagonists did not discuss the process of change and did not recognize the potential role of congressional acquiesence as a legitimating process equal to formal Senate consent or a statute.

Senator Biden was clear: an entrenched rule can only be changed by the same formal process by which it was created, consent by twothirds of the Senate. ${ }^{2}$ The Biden Resolution subsequently was amended to acknowledge that an entrenched rule could be changed by statute. ${ }^{3}$ Sofaer did not seem to address the question at all. Koplow acknowledges that the President would not be "estopped" from reinterpreting an entrenched term, that the "meaning of a treaty . . . remains free to evolve over time as circumstances warrant," and even that constitutional principles "do not require that the meaning of a treaty must be permanently frozen until a subsequent law-making activity fulfilling the requirements of bicameralism and presentment explicitly supercedes it." ${ }^{25}$ But his conclusion, quoted above, seems to require formal Senate or congressional action to legitimate an executive reinterpretation of an entrenched meaning.

Like other participants in the debate, ${ }^{6}$ Koplow overlooked the pro-

2 See The ABM Treaty and the Constitution, Joint Hearings Before the Senate Foreign Relations Comm. and the Senate Judiciary Comm., 100th Cong., 1st Sess. 2 (1987) [hereinafter as Hearings].

3 See S. Res. 167, reprinted in Senate Foreign Relations Comm., The ABM Treaty Interpretation Resolution, S. Rep. No. 164, 100th Cong., 1st Sess. 117 (1987) [hereinafter ABM TREATY INTERPRETATION REPORT].

4 Koplow, supra note 1 , at 1426.

Id. at 1407 .

-See, e.g., Glennon, Interpreting "Interpretation": The President, the Senate, and When Treaty Interpretation Becomes Treaty-Making, 20 U.C. DAvis L. REv. 913 (1987) (analyzing limits on presidential interpretive power to alter or amend treaties); Kennedy, Treaty Interpretation by the Executive Branch: The ABM Treaty and "Star Wars" Testing and Development, 80 AM. J. INT'L L. 854 (1986) (arguing that the Senate's understanding at the time of consent is binding on the President). 
cess of constitutional common law-making that was going on in the course of the reinterpretation dispute. The process by which the dispute was resolved - a presidential proposal rejected by the Congress - is a constitutionally correct procedure for law-making, and the substantive result - testing of exotic systems in space is not permitted by the ABM Treaty - was clearly correct. In the senatorial and academic debate, however, critics of executive power undervalued the role of presidential initiative in foreign policy law-making, and failed to take account of the potential role of Senate or congressional acquiescence in that process. And - somewhat incidentally - they overestimated the role of the Judiciary at the expense of the common law-making function of joint executive-congressional interaction and decision-making.

\section{A. Background}

When the President sent the ABM Treaty to the Senate for its advice and consent to ratification, Executive Branch officials told the Senate that the treaty prohibited the testing in space of exotic ABM systems (i.e. those based on "other physical principles" than those existing in 1972, like lasers). ${ }^{7}$ Thirteen years later the Reagan Administration "reinterpreted" the treaty to permit the testing in space of exotic ABM systems. However, Senator Nunn, supported by former officials who negotiated the treaty and several academic commentators, thoroughly demolished the Administration's case. ${ }^{8}$ The Administration arguments were so weak that the Senate Foreign Relations Committee questioned the good faith of their authors. 9

Most of the discussion of this problem in Senate Hearings, in a report of the Senate Foreign Relations Committee, and on the Senate floor focused on the substantive merits of the reinterpretation. However, Senator Biden took the lead in transforming the substantive arms control treaty question into a constitutional issue. He even urged his colleagues to treat the constitutional issue as "paramount" over the substantive, arms control question. ${ }^{10}$

7 For a summary, see Ass'N of the Bar of the Gity of New York, The ANTi-Ballistic Missile Treaty InTerpretation Dispute (1988).

- See Hearings, supra note 2, at 553-811 (Nunn analysis); Chayes \& Chayes, Testing and Development of "Exotic" Systems Under the ABM Treaty: The Great Reinterpretation Caper, 99 HARv. L. REv. 1956 (1986) (criticizing the Administration's reinterpretation as violating both the letter and spirit of the Treaty and professional responsibility); Garthoff, History Confirms the Traditional Meaning, ARMs ConTroL TODAY, at 15 (April 1987); Rhinelander \& Ruben, Mission Accomplished, ARMS Control Today, at 3 (Sept. 1987).

- See ABM TREATY INTERPRETATION REPORT, supra note 3, at 62.

10 See Hearings, supra note 2 , at 116. 


\section{B. The Constitutional Debate and Its False Formal Entrenchment Assumption}

Senator Biden introduced the ABM Treaty Interpretation Resolution ("S. Res. 167") on March 11, 1987, and convened a Joint Hearing of the Senate Judiciary and Foreign Relations Committees the same day. S. Res. 167 provided that "during the period in which a treaty is in force, the meaning of that treaty is what the Senate understands the treaty to mean when it gives its advice and consent . . . ."11 In his opening statement at the hearing Senator Biden explained that "during the life of the treaty the Constitution permits . . . only that interpretation [as presented by the executive branch and as understood by the Senate], unless the treaty is formally amended with the advice and consent of the Senate."12 Consequently, S. Res. 167 reflected a stark assertion of formal entrenchment. In support of the effort to prevent the President from reinterpreting the ABM Treaty to permit testing exotic ABM systems in space, S. Res. 167 would have frozen all treaty interpretations "as understood by the Senate" at the time of consent to ratification; the President could not suggest differently unless he received a new, formal Senate consent (presumably by an affirmative vote of two-thirds of the Senators present).

The Reagan Administration responded with the Sofaer Doctrine. According to this Doctrine, a particular interpretation would become entrenched if it were "authoritatively shared with, and clearly intended, generally understood and relied upon by, the Senate at the time of its advice and consent to ratification." 13 The Sofaer conditions for entrenchment clearly were intended to be more difficult to meet, thereby giving the Executive more latitude, but the concepts are so vague under both S. Res. 167 and the Sofaer Doctrine that it is far from clear that the two formulations would necessarily produce different results in practice. "Generally understood" and "understood" are not necessarily different. Any formal communication to the Senate could easily be regarded by an interpreter to be "clearly intended" to contribute to the Senate's understanding. And any statement received from the Executive in a Senate hearing could reasonably be presumed to be "relied upon."

11 S. Res. $167, \S 2(2)(\mathrm{A})$, reprinted in Hearings, supra note 2 , at 230 . The remaining relevant provisions of S. Res. 167 said that, in the absence of any Senate understanding on a particular point, the treaty is properly interpreted by a reference to the "text, as reasonably construed, in light of its object and purpose." Id. at 230.

12 Hearings, supra note 2, at 116.

13 Senate Foreign Relations Comm., The INF Treaty, S. Exec. Rep. No. 15, 100th Cong., 2d Sess. 443 (1988) [hereinafter INF REPORT] (Culvahouse letter); see also 134 Cong. Rec. \$6740-44 (daily ed. May 26, 1988) (Sofaer speech). 
Indeed, Senator Nunn recognized that the two tests were not far apart, ${ }^{14}$ but most protagonists in the debate underestimated the indeterminate quality of the concepts involved.

Koplow offers eight factors to balance in determining whether a meaning is entrenched. ${ }^{15}$ To some extent they cover the same ground as S. Res. 167 and the Sofaer Doctrine. Thus "what the Senate said," "what was said to the Senate," and "support for the old and new interpretations in the treaty text and record" (factors one, two, and four) seem similar to the concept of a Senate "understanding" that it "relied on." Factors six and seven focus on the magnitude of the change in interpretations, but seem only to add to the vagueness and manipulability of the inquiry (for which Koplow criticizes Sofaer). In any case likely to be contested, the Koplow factors would seem to make it easier for resourceful lawyers to support a preferred result.

The most problematic of Koplow's factors are the proposed use of subsequent practice, the agreement of the other party to the proposed reinterpretation, and changed circumstances. These are factors that only could occur after a meaning has been entrenched. As indicated, entrenchment occurs when the Senate votes to consent to ratification of the treaty. If Koplow's last three factors are relevant - as they surely are - it is difficult to see how any meaning could ever be assuredly entrenched. A meaning could only be tentatively entrenched. Although the inclusion of these factors is clearly a sensible approach, it shows up the vacuity of the intellectual framework in which this part of the debate was conducted.

Despite persistent efforts by Senator Biden and his allies to secure Senate endorsement of some form of the entrenchment principle, the Senate declined to do so - for perfectly good reasons. The notion that a legal rule - whether it is a constitutional provision, a contract term, or a treaty interpretation - can be fixed or "entrenched," subject to change only by formal process, is clearly unsound. The idea of entrenchment, based on the shared understanding of the Executive Branch and the Senate, is closely related to the nostalgic appeal to "original intent" as a way of ascertaining the meaning of the Constitution, and is subject to the same criticism. First, there are many intents behind the actions of a collective deliberative body, and most participants in the deliberation are silent. For example, during the later constitutional debate over treaty interpretation on the Senate floor, when the successor ${ }^{\circ}$ to S. Res. 167 was considered, only twenty-two Senators

14 See 134 Cong. Rec. S6778-89 (daily ed. May 26, 1988).

1s See Koplow, supra note 1 , at 1419-25. 
spoke. ${ }^{16}$ Fourteen endorsed the entrenchment provision but reflected three different views of its import. We do not know the views of the silent majority. It would not be implausible to believe that at least some intended that their intent not govern future interpretations. ${ }^{17}$ Given the number of participants in the deliberative process of treaty consideration by the Senate, it is often difficult to infer a single, coherent interpretation. Moreover, even if it were possible to make inferences from the statements of a few Senators, the interpreter can manipulate the result by varying the level of generality to which she takes the inference. Finally, as a practical matter, reference to the statements of one Senator, even a floor manager, can frequently be refuted by some other authoritative source. In the end the interpreter must choose which of the conflicting considerations to emphasize.

Under the standard canons of legislative history, however, the statement of a floor manager, arranged colloquies, and committee reports can eliminate the problem of multiple voices and seem to provide a coherent explanation of meaning. Nevertheless, as demonstrated by the debate over the successor to S. Res. 167, the single voice of the floor manager may not cover important points, may be internally inconsistent, and may even speak to a position not in fact embodied in the document before the Senate. Finally, the committee's reports are written by staff and are probably read by few, if any, Senators.

In view of the problems outlined above in divining legislative "intent" or a shared Senate understanding of a treaty meaning, the best measure of Senate intent is what it actually voted on. The meaning of what the Senate approved can be especially illuminated by comparing the approved version with proposals that a measure's proponents would like the Senate to have voted on, but were modified to attract the necessary votes for passage. The treaty interpretation debate showed that the Senate itself did not accept the general notion of formal entrenchment embodied in S. Res. 167 and the related Senate Foreign Relations Committee Report.

In the hearings, the original language of S. Res. 167 was criti-

${ }^{16}$ For a review of the debate, see 134 CoNG. Rec. S6724-83 (daily ed. May 26, 1988). The Senate subsequently debated and rejected an amendment proposed by Senator Specter that would have codified the Sofaer Doctrine. See 134 CoNG. REC. S688490 (daily ed. May 27, 1988).

${ }_{17}$ Cf. Powell, The Original Understanding of Original Understanding of Original Intent, 98 HARv. L. REv. 885 (1985) (analyzing and questioning the claim that the Constitution's Framers wrote it anticipating that future interpretations would rely on their original intent); Sherry, The Founders' Unwritten Constitution, 54 U. CHr. L. REv. 1127 (1987) (arguing that the Framers' expected future interpretations to preserve natural law were not expressly mentioned in the written Constitution). 
cized on legal grounds by Senators Lugar and Helms and by two private commentators. ${ }^{18}$ The private commentators specifically argued that interpretations may change over time, in response to new conditions and subsequent practice. Both private commentators called attention to the role of Senate acceptance of subsequent practice as a way of legitimating a reinterpretation. S. Res. 167 as reported reflected a significant change from the original formal entrenchment assumption. It provided that the meaning of a treaty provision "is to be determined in light of what the Senate understands the treaty to mean when it gives its advice and consent."19 The Committee Report, however, clung to the original entrenchment idea, asserting that "the meaning of the treaty that the President ratifies is the meaning on which there existed a meeting of the minds between the President and the Senate at the time of Senate consent." ${ }^{20}$ It quoted former Chairman Fulbright to the effect that "a law means what its framers intended it to mean and not what a later generation of policy makers would like it to mean ....."21

Senator Helms, on the other hand, characterized this part of the Committee Report as an attempt to "rewrite constitutional law." $22 \mathrm{He}$ explained that "[s]ubsequent practice gives to the Chief Executive the right to adjust the implementation of a treaty."23

Both views are wrong. No meaning of a treaty, contract, or law is fixed forever but, contrary to Senator Helms, the President cannot unilaterally reinterpret a treaty. Formal Senate action is not necessary, but Senate acquiescence is.

The Senate Foreign Relations Committee voted to report S. Res. 167 , as amended, favorably by a vote of $11-8 .{ }^{24}$ Since the Resolution dealt with the substantive law of the ABM treaty as well as with the constitutional law of treaty interpretation, it is impossible to know whether some Senators may have agreed with the initial interpretation of the ABM Treaty, but may have disagreed with (or may have not had a view on) the constitutional principles contained in the Resolution, or vice versa. Such are the vagaries of legislative intent. In any event, the Senate did not take action on the Resolution, but Congress did - informally - frustrate the Reagan reinterpretation of the ABM

18 See Hearings, supra note 2, at 180-81 (Senator Helms); id. at 182-83 (Senator Lugar); id. at 86-87 (Professor Baldwin); id. at 192-95 (Mr. Rovine). added).

10 ABM TREATY INTERPRETATION REPORT, supra note 3, at 117 (emphasis

20 Id. at 39.

21 Id.

22 Id. at 69

23 Id.

24 See id. at 37. A Helms substitute motion failed by a vote of 9-10. 
Treaty by limiting appropriations for SDI. Thus, Congress imposed its view of the substantive law of the ABM Treaty, but did not express its view on the constitutional principles of treaty interpretation. The Senate inaction was apparently part of a political compromise under which the Reagan Administration agreed to conform to the narrow interpretation of the ABM Treaty and the Senate agreed to "temporarily forego legislation that endorses the restrictive view of the treaty."25 By declining to act on the Foreign Relations Committee recommendation, the Senate laid the foundation for a negative implication; it did not wish to endorse the constitutional law principles embodied in S. Res. 167, as amended.

The Biden Resolution, S. Res. 167, and the issue of entrenchment, however, were not dead. In connection with the popular INF Treaty, the proponents of S. Res. 167 found a new opportunity to press the issue. The Biden Resolution, S. Res. 167, was revived as a proposed condition to the INF Treaty. ${ }^{28}$ The Biden Condition embodied the old entrenchment principles: the United States shall not agree to an interpretation of a treaty different from the original understanding except by formal Senate consent. The purpose of the Biden Condition was "to articulate and affirm . . . constitutional principles" that "reflect long-standing constitutional practice." ${ }^{27}$ The Biden Condition was directed "to the maximum degree possible" to the INF Treaty, but it was also designed to "affirm principles that inherently apply to the INF Treaty."28 The Committee responded to the objection that the Senate cannot change the Constitution by a unilateral resolution or condition by stating that it was necessary in the context to register its non-acquiescence to the Sofaer Doctrine. Thus the Biden Condition, "paradoxically . . . [was] both unnecessary and highly significant."29

The Biden Condition specifically provided that the INF Treaty "shall be subject to the following principles, which derive, as necessary implications, from the provisions of the Constitution (Article II, section 2, clause 2) for the making of treaties . . . ."30 The Committee's attempt to secure Senate approval of this general statement of constitutional law was once again unsuccessful. On the floor of the Senate, a

${ }^{25}$ A. Gordon, Nunn says Record on the ABM Pact is Being Distorted, N. Y. Times, Mar. 12, 1987, at A1, col. 4.

${ }^{26}$ See INF REPORT, supra note 13, at 97, 436.

27 Id. at 96.

${ }^{28} I d$. at 97 (emphasis in original).

$28 \mathrm{Id}$.

${ }^{30} I d$. The Condition then set forth the original entrenchment principles of S. Res. 167. 
substitute condition, now called the Byrd amendment, ${ }^{31}$ deleted the language quoted above that indicated that the entrenchment principles were general principles of constitutional law. Instead, entrenchment principles were applied as a condition to the INF Treaty, and were by their terms limited to that treaty.

The change was intentional and significant. During the Foreign Relations Committee deliberations, Senator Cranston, who took over leadership of this issue in the absence of Senator Biden, proposed three versions of the Biden Condition to Senator Lugar. Lugar rejected all three. Cranston then "introduced the toughest of the three, including the claim of constitutional authority, giving himself room to negotiate when the treaty reached the full Senate."32 As the debate on the Senate floor moved toward consideration of amendments and conditions, "Cranston said that he and Pell would be willing to remove the reference to constitutional authority from the language."33 This is exactly what happened. The entrenchment provisions embodied in the Condition were no longer said to "derive, as necessary implications, from the provisions of the Constitution." Instead, the Senate adopted a "condition, based on the Treaty Clauses of the Constitution," to the effect that the original understanding of the INF Treaty - and only that Treaty - would be entrenched. ${ }^{34}$ Once again, the Senate deliberately - and as part of a political compromise - declined to endorse the general "consitutional principles" embodied in S. Res. 167 and the Biden Condition. Nevertheless, despite the language change, several Senators in the floor debate maintained that the revised Condition would still have the effect of making a general statement about constitutional law; in other words, a statement in favor of formal entrenchment. ${ }^{35}$ That view, however, was not the only view expressed by supporters of the Byrd amendment, and it is therefore not necessarily indicative of Senate intent. Fourteen Senators spoke in favor of the Byrd amendment. Eight interpreted the amendment to represent a general statement, while two others seemed to accept that it had no effect beyond the INF Treaty. Other supporters did not address the question. There obviously was no

31 See 134 Cong. Rec. S6724 (daily ed. May 26, 1988).

32 Abramson, Democrats Ready to Compromise on Key INF Issue, Cranston Says, L.A. Times, May 20,1988, pt. 1 at 16, col. 1 .

${ }^{33}$ Id.

${ }^{34}$ The reference to the Treaty Clauses of the Constitution may still seem ambiguous. Literally it could either mean that the substance of the Condition was based on constitutional law, or it could mean that the Senate's action - procedurally - was based on the Constitution. Since the former would render the language change meaningless, the latter seems correct.

ss See supra note 15. 
single view among the supporters who spoke as to the correct meaning or message of the Byrd amendment.

Only two Senators directly addressed the effect of the language change from the original Biden Condition. Senator Lugar, who both participated in the discussions leading to the compromise language in the amendment and voted for the amendment, offered the following view:

I rise to ask Senators to vote for the Byrd substitute. I do so having participated in the discussions with the distinguished majority leader, with colleagues on both sides of the aisle representing the Foreign Relations, Armed Services, and Intelligence Committees, and of course, our Republican leader, Senator Dole. . . . I hoped this particular amendment would not be necessary on the INF Treaty. Indeed, I described the entire operation as a mistake, in my judgment. I suspect that each one of us tries to determine what is relative and what is important, and it is apparent to me that a number of colleagues believe this matter is very important. Indeed, the majority leader has pointed out that in his judgment the role of the Senate in the treaty-making process is the most important factor superseding even perhaps the treaty we are discussing.

I would say Mr. President, that my judgment about these matters is somewhat reversed. I come to a conclusion of support for this amendment because I believe the INF Treaty is very important, and it is apparent to me that the passage of this treaty would have been difficult within the time period which we are talking about without accommodation of colleagues listening to one another ....36

Senator Dole, another participant in the compromise discussions and a reluctant supporter of the amendment, echoed similar sentiments:

As I have discovered over the years, there are about three ways in this body to deal with disagreements.

We can argue and argue, ad infinitum; and produce little but an especially fat edition of the Congressional Record. Or we can put down our honest differences in pretty stark form, and then vote-up or down, winner take all.

Or, finally, we can look for compromise. It seemed to me after several hours of meetings that was our only real 
choice, if we wanted to get this treaty done, without a truly dangerous and damaging amendment attached to it. . . .

I want to correct any misunderstanding. The White House is not supporting this compromise. . . They wanted some changes. They wanted some changes we did not give. Some of the changes were made: compromise.

So I think if I had my way this amendment would not be on this treaty. I do not think it even belongs here. But I know who is in the majority and I know where the votes are and I knew that the majority leader felt strongly about this issue on one side. Many others felt strongly on the other side. ...

And so we did the best we could. The result, to me personally, is far from the best solution; again, I suggest that I am not the constitutional scholar. But to me, sincerely, it is the best we can achieve.

We ended up with a better result than we started with. The majority leader and others on that side were willing to make some concessions. I think one key provision and one addition was what we call subsection (4). . .

That provision makes clear, at least it does to me, that the decision we are making on this treaty applies solely to this treaty and does not prejudice our position on the ABM interpretation issue at all. . . .

It is my understanding, based on the conversations and I do not believe I missed much of any of the meetings, that was pretty well the feeling of most participants, Republicans and Democrats - that was the effect of that subsection (4). ${ }^{37}$

Perhaps significantly, in his response to the Dole statement that concluded the debate, Senator Byrd focused his constitutional arguments on the INF Treaty alone. ${ }^{38}$

In the debate, therefore, there was no single or clear explanation of the language change. Many voices spoke. Some continued to see an affirmation of general constitutional principles. Others viewed the debate as another version of the ABM Treaty dispute. Still others opposed the general principles embodied in the original Biden Condition, but went along with the compromise in order to get the INF Treaty approved in time for the Moscow summit. Even supporters of the origi- 
nal Condition were willing to give up Senate endorsement of general constitutional principles in order to avoid delaying the INF Treaty, a politically untenable position for arms control supporters. Hence the compromise referred to by Senators Lugar and Dole. The most plausible inference is that the Senate decided to avoid a general constitutional statement. They entrenched the original understanding of the INF Treaty, but did nothing else. ${ }^{38}$

Unfortunately the debate did not reflect much discussion of the related question of how an entrenched meaning can change. Only Senator Lugar spoke on this point:

I point out, furthermore, that the checks and balances of our Government still work, and I appreciate the frustration of many colleagues on the other side of the aisle who feel that the current administration has attempted to reinterpret a treaty. In my own judgment, the current administration did not attempt to reinterpret treaty. The ambiguity at least in the ABM Treaty has been cited by the administration as a basis for interpretation. But let us take the worst case, that the current administration deliberately took a look at a proposition that both the Senate and the President had looked at and went entirely in a different direction. In truth, Mr. President, we have in front of us the actual political history of the past 2 years, and that is the majority party in the Senate has not agreed with the interpretation of the President of the United States of how we ought to develop the SDI program, and as a result that program has either been stymied or has been tailored to fit the will of the majority.

Now, I have not agreed with the tailoring or the stymieing, but nevertheless, I recognize that in our political system this is the way it works. In short, even if a President should attempt to reinterpret a treaty, the checks and balances of the legislative-executive relationship check any exercise of arbitrary judgment or arbitrary authority.

Therefore, Mr. President, I saw no particular reason to

39 The next day Senator Specter offered an amendment to the effect that neither the Biden Condition, as amended, nor the Foreign Relations Committee Report on the INF Treaty would change existing constitutional law. That amendment was rejected, by a vote of $64-33$, arguably creating a negative implication that the Senate did seek to change constitutional law. Nevertheless, the four Senators who spoke in opposition seemed to regard this amendment merely as a threat to the earlier compromise reached on the Byrd amendment and as means of reviving the Sofaer doctrine. At least two also interpreted it as an attempt to elevate the status of international law over the constitutional law of the United States. See id. at S6890-91. 
try to pin all of this down 15 different ways. It seems to me the system works adequately as it stands . ... .40

\section{G. Formal and Informal Processes of Legal Development}

An integral part of the idea of entrenchment was the assumption that the original, frozen meaning can only be changed by the same formal process that created the norm in the first place. This aspect of the constitutional debate is the most troubling. It fails to take account of the informal ways in which legal meaning can change over time. Koplow acknowledges that law changes over time, but does not address the potential for informal processes of change. It ought not to be controversial that a legal rule can be changed in content by a method different from that which produced it originally. The Constitution has been fundamentally transformed by legislative action, in opposition to or at variance with the formal amendment procedure contained in the Constitution. The legitimating factor was popular acquiescence in the revised order. $^{41}$

In addition, the original understanding of the Treaty Power, ${ }^{42}$ which envisioned Senate consultation prior to the negotiation or conclusion of treaties, was quickly reinterpreted in an informal manner. In 1789 , in connection with an upcoming negotiation. President Washington went before the Senate and asked its advice on a series of specific negotiating questions. The Senate postponed consideration of all but one such question to a second session. The procedure was unsatisfactory both to the President and the Senate, and was abandoned. Even the practice initiated by President Washington of seeking written advice on particular negotiating questions was abandoned by Washington before the end of his first Administration..$^{43}$ Because Washington presided at the Constitutional Convention and most Senators participated in some formal way in the Constitution's preparation or ratification, the early experience would seem to reflect the original understanding.

The original understanding of the Senate's role in treaty-making, however, continued to change over time in light of experience. "By 1816 the practice had become established that the Senate's formal participation in treaty-making was to approve, approve with conditions, or

$10 \mathrm{Id}$. at $\mathrm{S} 6771$.

41 See B. Ackerman, Discovering the Constitution (forthcoming).

42 See U.S. CoNST. art. II, $\S 2$, cl. 2.

43 See Congressional Research Service, Treaties and Other International Agreements: The Role of the United States Senate, S. Prt. 98-205, at 25-34 (Comm. Print 1984). 
disapprove treaties after they had been negotiated by the President or his representative."44 The lesson is that the original entrenched meaning of a constitutional term can be changed, even over a relatively short period of time, by subsequent history. Moreover, the process consisted of executive initiative and senatorial acquiescence. An attempt in 1973 by Senator Hartke to reaffirm the "historic" role of the Senate in treaty-making by constituting it as a council of advice for that purpose came to naught in the face of executive constitutional objections. ${ }^{45}$

The history of executive agreements also illustrates how practice can alter the entrenched scope of the Article II treaty power. Against a lack of original understanding, or even a negative intention, ${ }^{\mathbf{4}}$ the President has used presidential executive agreements to create international and domestic law. The Supreme Court has legitimated these developments and has approved the informal, law-making process of presidential initiative and congressional acquiescence. ${ }^{47}$

The War Power is another example of an entrenched constitutional meaning that has been changed by informal amendment. It seems to be accepted that the original understanding of the War Power was that the United States could only initiate the use of military force by a declaration of war by Congress, except in some limited circumstances of self-defense. ${ }^{48}$ Over time the congressional role was eroded, ${ }^{49}$ and since World War II the President has frequently initiated military activities without such a declaration. Examples include the military action in Korea, the Dominican Republic, Lebanon, Grenada, and the Persian Gulf. In 1973 Congress passed the War Powers Resolution to recapture its historic, constitutional role; that is to establish the continuation of the entrenched meaning of the constitutional provision. ${ }^{50}$ The President vetoed the Resolution and took the position that it was unconstitutional. ${ }^{\text {s1 }}$ Subsequent Presidents have disregarded its major limitation,

14 Id. at 36 .

15 S. Res. 99, 119 Cong. Rec. 7274-75 (1973), was opposed by the Department of State on the grounds that the consistent practice since Washington had been to consult but not to use the Senate as a "Council of Advise." Digest of UnITEd STATes Practice in InTernational Law 172-76 (A. Rovine ed. 1973).

to See Berger, The Presidential Monopoly of Foreign Relations, 71 Mrch. L. REv. 1 (1972).

47 See Dames \& Moore v. Regan, 453 U.S. 654 (1981).

${ }^{48}$ See Ely, Suppose Congress Wanted a War Powers Act That Worked, 88 Colum. L. Rev. 1379, 1389 n.34 (1988).

49 See Note, Congress, the President, and the Power to Commit Forces to Combat, 81 HaRv. L. REV. 1771, 1790 (1968).

so Pub. L. No. 93-148, § 2, 87 Stat. 555 (1973) (codified at 50 U.S.C. § 1541-48 (1982)).

si See President's Message to the House of Representatives Returning H.J. Res. 542 Without His Approval, 9 Weekly Comp. Pres. Doc. 1285 (Oct. 24, 1973). 
and Congress has not used its legislative or appropriations powers to reverse the presidential position. ${ }^{\mathbf{5 2}}$ It is fair to conclude that the constitutional allocation of war powers has been changed, again by presidential initiative and congressional acquiescence.

The entrenched, original meaning of other legal norms, including statutory provisions and contract terms, can be similarly amended by informal process. That process was exactly what was engaged during the ABM Treaty interpretation controversy. The Treaty had an original or arguably entrenched meaning, which the President proposed to change. In rejecting the presidential initiative through its legislative power, the Congress confirmed the original meaning, thereby winning the battle over the substantive law of the ABM Treaty.

On the other hand, the congressional proponents of formal entrenchment and curtailment of executive power lost the battle over constitutional principle. The Biden Resolution was first amended and then abandoned. The Senate did not approve S. Res. 167, S. Res. 167 as amended, or the Biden Condition as initially proposed. Therefore, the resulting constitutional common law of treaty interpretation was to reject the general statements of constitutional law embodied in the Biden Resolution and Condition with their formal entrenchment assumptions.

This clash of constitutional claims, reflected in the debate and the resulting Senate action or inaction, provide the best available evidence of constitutional principle in this area. The Judiciary rarely decides foreign policy-separation of powers cases. The most active decisionmakers are Congress and the Executive Branch. Their interaction and joint decision reflect a kind of constitutional common law. ${ }^{53}$ Indeed, in this respect, the two political branches may properly be viewed as an

s2 See Ely, supra note 48, at 1379 (noting that Congress has "lain back, neither disapproving presidential military ventures nor very explicitly approving them, trusting the President to take the lead and waiting to see how the war in question played politically"). See generally, Glennon, The War Powers Resolution Ten Years Later: More Politics Than Law, 78 AM. J. INT'L. L. 571 (1984) (congressional complacency creates a serious obstacle to strengthening the Resolution).

${ }^{33}$ In the Senate deliberations, see infra text accompanying notes 18-40, several Senators and commentators indicated that the Supreme Court would or could have the final word. In fact, the Judiciary does not hear many foreign policy or separation of powers cases. And historically, some have argued that presidential and congressional views or questions of constitutional law are entitled to at least equal weight. See L. Fisher, Constitutional Dialogues: Interpretation as Political Process 3$5,235-42$ (1988). In any event, most foreign affairs issues are settled by the political branches, not the Judiciary. Consequently, their decisions, reached through compromise in the political process, and their opinions, reflected in public debate, should be accorded primary legal significance in this area of law. Cf. Glennon, The Use of Custom in Resolving Separation of Powers Disputes, 64 B.U.L. REv. 109, 134-47 (1984) (suggesting that courts should examine juridical norms found in political branch acts, notice and acquiesence in establishing custom as a basis for resolving inter-branch disputes). 
elected judiciary, making decisions on the legally correct boundaries of separated powers in foreign policy, and being held regularly accountable to the voters for those decisions. For this reason, the terms of the debate and the joint decisions reflected in the ultimate disposition of the Biden Resolution and the Biden Condition are the best evidence of the current constitutional common law of treaty interpretation.

The Senate Foreign Relations Committee and Professor Koplow concede that modifications in a treaty may be authorized by statute. ${ }^{54}$ There is no reason why they may not equally be modified by acquiescence. The burden of showing acquiescence may be heavy - the practical application of this alternative would normally be in cases that are minor or uncontroversial. But the extensive use of "historic practice" as a source of authority in general constitutional interpretation shows that informal amendment processes are legitimate. ${ }^{55}$ As Senator Lugar noted, the reinterpretation controversy showed that "checks and balances" worked. Indeed, it also showed how the process of treaty reinterpretation can work, through presidential initiative and congressional reaction, whether formal or informal. The most basic conceptual flaw in the formal entrenchment assumption and in the Senate and academic debates was to undervalue the importance of presidential initiative.

\section{Presidential Power and the Ideology of United States Foreign Policy}

Professor Koplow's analysis is part of a literature that is generally critical of executive power and advocates congressional recapture of its "historic" or "proper" constitutional role. ${ }^{56}$ These attacks on executive power normally seek to insert congressional participation into the foreign policy decision-making process involving decisions such as making certain national commitments, initiation of military force, authorization of specific covert intelligence activities, approval of particular arms sales and nuclear exports, trade retaliation, and, in the case discussed

s4 See e.g., INF REPORT, supra note 13, at 99. This is another example of amendment of Article II by informal process. Presidents have concluded major agreements on this basis to such an extent that it is now well established that the two forms of agreement authorization are constitutionally equivalent. See L.K. JoHnson, THE Making of International Agreements 12 (1986).

so See generally Dames \& Moore v. Regan, 453 U.S. 654 (1981) (upholding executive power to suspend claims against foreign nation when Congress acquiesced).

${ }^{58}$ See, e.g., T. Franck \& E. Weisband, Foreign Policy by Congress (1979) (discussing the post-Vietnam War shift of foreign policy power from the Executive to Congress); Ely, supra note 48, Koh, Why the President (Almost) Always Wins in Foreign Affairs: Lessons of the Iran-Contra Affair, 97 YALE L.J. 1255 (1988) (arguing that the Iran-Contra scandal exemplifies a chronic dysfunction in the structure for the conduct of present U.S. foreign policy). 
here, treaty interpretation. Most of the attacks grow out of particular presidential decisions that have gone wrong or have proven otherwise unpopular and feed on the general mistrust of the Presidency engendered by the Vietnam War and the Watergate debacle. Critics of the Executive believe that by inserting Congress or the Senate earlier into the presidential decision-making process, they will prevent unwise commitments, wars, embarrassing covert actions, and ill-advised treaty interpretations.

This approach is wrong for two basic reasons. Most importantly, the diminution of presidential power sought by the critics would undermine important elements of the prevailing ideology of United States foreign policy. ${ }^{57}$ Without realizing it, the critics of presidential power are implicitly attacking the vision of American world leadership that is fundamental to the national self-image. That leadership would be significantly less effective in a world of formal congressional co-determination of specific decisions in foreign policy. In addition, Congress accepts this prevailing world leadership ideology and does not want to play the role that the critics would have it play. Congress is a political body that recognizes the value of presidential initiative in bolstering the traditional ideology.

Since the establishment of the Massachusetts colony, the elite who defined American culture have portrayed America as a unique society that should serve as an example for the rest of the world to follow. ${ }^{58}$ From Winthrop's "city on a hill" sermon through Manifest Destiny and Wilsonian idealism, the United States has sought to mold other nations and societies in its own self-image. Infused with a sense of national greatness, the United States Government has promoted political liberty and capitalist economics as an integral part of its foreign policy. Since World War II, this intellectual tradition has been manifested in the American rhetorical assumption of "leadership of the free world," its promotion of "international human rights," and its creation of international free-market or "open" economic regimes. The leadership/example ideology has been reflected in central political, military, economic, and social policies of the national government.

In the political sphere, the United States has supported the advance of democracy through overt and covert means. In face of "communism," the mantle of support even has been extended to many governments and movements opposed to revolution regardless of their

67 See generally M. Hunt, Ideology and U.S. Foreign Policy (1987) (arguing that critics calling for greater restraint in foreign policy pay inadequate attention to the ideological roots underlying that policy).

${ }^{68}$ See W. LaFeber, The American Age 9, 19 (1989). 
actual political system, as long as they could be rhetorically counted as part of the "free world." 59 From the initial authorization of the CIA in 1947, Congress recognized that covert action was an important part of this strategy, ${ }^{60}$ and that the Executive needed the authority to carry out individual operations, at times and in places of its own choosing, free of a requirement of specific prior congressional authorization. ${ }^{61}$ Even after the scandals revealed by the Watergate investigations, Congress declined to require specific advance authorization of particular covert operations. This congressional decision was taken in the face of an executive claim of implied constitutional foreign affairs power to initiate covert actions. ${ }^{62}$ Consequently, congressional inaction may be taken as acquiescence in the executive claim. Even after the Iran-Contra scandal, Congress continued to respect the value of presidential initiative and declined to require advance notice or approval of covert operations.

In the military sphere, the United States "leadership of the free world" has been buttressed by a series of alliances, bases, and troop deployments to deter communist aggression and suppress unwelcome revolutionary activity. The implementation of this policy has required regular, and often controversial, presidential military action; Congress, however, has regularly authorized and acquiesced in its use. Even the War Powers Resolution, which was specifically passed in the aftermath of the Vietnam War to curtail executive use of military force, has not effectively curtailed executive initiative. President Nixon vetoed it as unconstitutional. President Reagan took action inconsistent with its terms, and Congress declined to enforce it. Again, presidential action and congressional acquiescence has created a broad constitutional common law protecting presidential initiative.

On the economic front, Congress has been more direct in supporting the presidential initiation function. It authorized American partici-

s9 See M. Hunt, supra note 57; see also W. Williams, The Tragedy of AMERICAN Diplomacy (1962) (emphasis on economic factors).

Bo See National Security Act of 1947, ch. 343, § 102, 61 Stat. 497 (codified at 50 U.S.C. $\S 403(d)(5)(1982)$ ) (authorizing the Central Intelligence Agency to "perform such other functions and duties related to intelligence affecting the national security as the [NSC] may from time to time direct"); see also W. LAFEBER, supra note 58, at 459.

${ }^{61}$ See generally J. OSETh, Regulating U.S. Intelligence OPERATIONS: A StUdy IN THE Definition of THE National INTERest (1985) (describing the congressional investigations of the 1970s and the subsequent adoption of permissive notice requirements for initiating special activities).

${ }^{62}$ See Congressional Oversight of Covert Activities, Hearings Before the House Select Comm. on Intell., 98th Cong., 1st Sess. 148-51 (1983); id. at 27-28 (Mr. Colby); U.S. Intelligence Agencies and Activities: The Performance of the Intelligence Community, Hearings Before the House Select Comm. on Intell., 94th Cong., 1st Sess. 1729-38 (1975) (Mr. Rogovin). 
pation through the Executive Branch in the World Bank and the International Monetary Fund (IMF), and delegated substantial authority to the President to enable United States participation in the General Agreement on Tariffs and Trade (GATT). Congress delegated virtually the entire foreign commerce power to the President under the Export Administration Act, trade legislation, and the International Emergency Economic Power Act (IEEPA). Most of the congressional complaints in this area have been based on its perception that the Executive Branch was not being active enough in defending American domestic interests. Congress has sought more rather than less executive initiative. Here, Congress also recognized that in the pursuit of United States economic goals the President needs broad authority to initiate action.

Culturally, the promotion of human rights has played a critical, but less criticized, role in carrying out the ideology of example and leadership. Since the founding of the United Nations, the United States has promoted western civil and political values as a model for the rest of the world to follow. In the vacuum created by the failing Nixon presidency, Congress forced human rights on the specific foreign policy agenda, but even then it recognized that only presidential action could translate the general policy into concrete results. Consequently, in the four major arenas in which American leadership/example ideology ${ }^{63}$ has played out, Congress has largely chosen to rely on and respect presidential initiative.

Although treaty interpretation plays a less important role in the grand scheme of United States foreign policy, it is an integral part of the day-to-day conduct of foreign relations that is the heart of the President's executive function. ${ }^{64}$ To freeze the executive ability to reinter-

${ }^{63}$ In the past decade or so, international interdependence has presented the historical ideology of American example and leadership with a fundamental new challenge. This new context of intense world involvement both threatens and stimulates the ideological self-image of American leadership. Interdependence is threatening because other nations have become relatively more powerful, heralding a new multi-polar world. The United States must take account of other nations' interests more regularly. The United States can no longer lead (or get its own way) in the manner that it used to. But the ideological self-image of American leadership is stimulated because interdependence requires more government action to defend the American economic, social, and political interests that the voters increasingly want advanced throughout the world. Interdependence will create more pressure on Congress to act. But, at the same time, interdependence requires day-to-day initiatives and responses that frequently can only be made by the Executive-dealing, for example, with exchange rates, oil supplies, enforcement of trade agreements, unwanted foreign investment, terrorism and human rights, disaster relief, nuclear non-proliferation, intifadeh in the West Bank, hostages in Lebanon, insurgency in the Sudan, and regrettably, military crises. Effective action to sustain some measure of American leadership will continue to require presidential initiative.

64 I am not arguing that executive power to interpret or reinterpret treaties is an 
pret treaties in some circumstances would undercut, albeit in a relatively minor way, the potential for presidential initiative in leading the nation in an interdependent world.

As mentioned, the formal entrenchment doctrine is part of a more general intellectual attack on presidential power. The critics should understand the difficulty of their task. They are not just attacking the ghost of Richard Nixon, but a deeply-rooted ideology. Moreover, it is an ideology shared to date by the Congress. The way that Congress has chosen to translate that ideology into practice is to authorize and tolerate presidential initiative. That is the basic constitutional common law of foreign policy and separation of powers. The President initiates. The Congress oversees, and reverses if necessary. That was the unnoticed lesson of the ABM Treaty reinterpretation dispute. By casting the problem as one of unilateral executive power versus formal Senate or congressional consent, the formalists overlooked the obvious, and historically sanctioned, intermediate process of constitutional common lawmaking that actually went on in the ABM Treaty interpretation dispute.

exclusive power, for as I said, it can be checked by the judiciary and the Congress. And it is limited by the need for concurrence by the other treaty partners and by the discipline provided by the need to justify the new interpretation under accepted forms of legal analysis. The substantive result of the ABM Treaty reinterpretation caper demonstrates the power of the last three factors. 